\title{
Managerial leadership and ischaemic heart disease among employees: the Swedish WOLF study
}

\author{
A Nyberg, ${ }^{1,2}$ L Alfredsson, ${ }^{3,4} \mathrm{~T}$ Theorell, ${ }^{2} \mathrm{H}$ Westerlund, ${ }^{2} \mathrm{~J}$ Vahtera, ${ }^{5} \mathrm{M}$ Kivimäki ${ }^{6}$
}

${ }^{1}$ Department of Public Health Sciences, Karolinska Institute, SE-171 77 Stockholm, Sweden; ${ }^{2}$ Stress Research Institute, Stockholm University, Stockholm, Sweden; ${ }^{3}$ Institute of Environmental Medicine, Karolinska Institute, Stockholm Sweden; ${ }^{4}$ Stockholm Center of Public Health, Karolinska University Hospital, Stockholm Sweden; ${ }^{5}$ Finnish Institute of Occupational Health, Helsinki, Finland; ${ }^{6}$ Department of Epidemiology and Public Health, University College London, London, UK

\section{Correspondence to:}

Anna Nyberg, Stress Research Institute, Stockholm University SE - 10691 Stockholm. Sweden; anna.nyberg@ki.se

Accepted 22 August 2008

\section{ABSTRACT}

Objective: To investigate the association between managerial leadership and ischaemic heart disease (IHD) among employees.

Methods: Data on 3122 Swedish male employees were drawn from a prospective cohort study (WOLF). Baseline screening was carried out in 1992-1995. Managerial leadership behaviours (consideration for individual employees, provision of clarity in goals and role expectations, supplying information and feedback, ability to carry out changes at work successfully, and promotion of employee participation and control) were rated by subordinates. Records of employee hospital admissions with a diagnosis of acute myocardial infarction or unstable angina and deaths from IHD or cardiac arrest to the end of 2003 were used to ascertain IHD. Cox proportionalhazards analyses were used to calculate hazard ratios for incident IHD per 1 standard deviation increase in standardised leadership score.

Results: 74 incident IHD events occurred during the mean follow-up period of 9.7 years. Higher leadership score was associated with lower IHD risk. The inverse association was stronger the longer the participant had worked in the same workplace (age-adjusted hazard ratio 0.76 (95\% Cl 0.61 to 0.96$)$ for employment for 1 year, 0.77 (0.61 to 0.97$)$ for 2 years, 0.69 (0.54 to 0.88 ) for 3 years, and 0.61 (0.47 to 0.80 ) for 4 years); this association was robust to adjustments for education, social class, income, supervisory status, perceived physical load at work, smoking, physical exercise, BMI, blood pressure, lipids, fibrinogen and diabetes. The doseresponse association between perceived leadership behaviours and IHD was also evident in subsidiary analyses with only acute myocardial infarction and cardiac death as the outcome.

Conclusion: If the observed associations were causal then workplace interventions should focus on concrete managerial behaviours in order to prevent IHD in employees.

A recent meta-analysis of prospective cohort studies examining determinants of cardiovascular disease, suggests an average excess risk of $50 \%$ in employees who are exposed to an adverse psychosocial work environment (eg, high job strain). ${ }^{1}$ These results have considerable clinical implications, especially since psychosocial stressors at work are relatively common. ${ }^{2}$

Before a consensus on psychosocial work environment as a major risk factor for cardiovascular disease can be reached, data from population interventions aimed at preventing this risk factor are needed. To date, no large scale evaluations of such interventions have been published, perhaps due to lack of knowledge regarding how such interventions should be carried out. To help define the interventions required, we tested whether concrete managerial behaviours promoting a favourable psychosocial work environment were associated with a reduced risk of cardiovascular disease among employees.

Observational evidence on various general conceptualisations describing leadership as predictors of employee health is accumulating. ${ }^{3}$ For example, considerate behaviour on behalf of the leader, structures initiated with consideration for the employee, and transformational behaviours (communication of a vision, intellectual stimulation, consideration of individual employees) have all been found to be related to good employee health, job satisfaction and productivity. ${ }^{4-13}$ A high level of justice in managerial behaviours has been shown to be related to increased employee motivation and cooperation, decreased levels of negative emotions and sickness absence, and reduced risk of coronary heart disease (CHD). ${ }^{14-20}$ In contrast, perceived abusive, passive-avoidant and laissez-faire leadership has been found to be associated with increased psychological distress, ${ }^{21-23}$ and lack of social support in combination with job strain has been shown to be related to elevated risks for cardiovascular disease and increased levels of sickness absence. ${ }^{24-26}$ Finally, a Swedish study found a decrease in serum cortisol levels and an improvement in perceived authority over decisions among employees whose managers participated in a psychosocial manager program compared with a control group. ${ }^{27}$

Many of the studies described above were based on cross-sectional designs, self-reported data and/ or assessments of managerial leadership defined in general terms of justice and support. The aim of the present study was to examine the association between employees' perceptions of managerial behaviours and objectively measured incident ischaemic heart disease (IHD) in a prospective research design, while adjusting for conventional cardiovascular risk factors. We focussed on concrete managerial behaviours, such as the manager's consideration for the individual employee, provision of clarity in goals and role expectations, supplying information and feedback, ability to carry out changes at work successfully, and promotion of employee participation and control (for a description of the measured leadership behaviours, see table 4).

\section{METHODS}

\section{Study population}

Data were drawn from the WOLF (Work, Lipids, and Fibrinogen) Stockholm study, which is a prospective cohort study of employees aged 19-70 
working in companies in the Stockholm area. Twenty occupational health units carried out the baseline screening between November 1992 and June 1995. Overall, 3239 men and 2459 women (76\% participation) took part in a clinical examination and a questionnaire survey. Records of hospital admissions and deaths to the end of 2003 were obtained from national registers and were linked to the data. The Regional Research Ethics Board in Stockholm, and the ethics committee at Karolinska Institutet, Stockholm, Sweden approved the study (nos. 2006/ 158-31, 2008/240-32, 92-198 and 03-125).

We restricted the analyses to men only since there were too few cases of ischaemic disease among women $(n=12)$. Cases of prevalent ischaemic disease at baseline in 1992-1995 identified by hospital admission for ischaemic disease between 1963 and baseline screening were excluded from the analysis (21 men). An additional 46 men were excluded because they were above 65 years of age (official retirement age) at the start of the study, and finally 50 men were excluded because of missing data in the managerial leadership scale.

\section{Clinical characteristics}

Education (low, intermediate, high) and smoking status (current smoker vs non-smoker) were self-reported, while income from work (in Swedish kronor) was obtained through registers. Systolic and diastolic blood pressure ( $\mathrm{mm} \mathrm{Hg}$ ) was twice measured on the right arm in the supine position after 5 min rest with a 1 min interval. Height, weight and waist were measured to determine body mass index (BMI, $\mathrm{kg} / \mathrm{m}^{2}$ ) and waist circumference $(\mathrm{cm})$. Blood samples were taken after an overnight fast and analysed in the same laboratory (CALAB Medical Laboratories, Stockholm, Sweden) accredited by the Swedish Board for Accreditation and Conforming Assessment. Total cholesterol ( $\mathrm{mmol} / \mathrm{l})$ and high density lipoprotein (HDL) cholesterol ( $\mathrm{mmol} / \mathrm{l})$ were measured enzymatically after precipitation with phospotungstic acid and magnesium chloride. Low density lipoprotein (LDL) cholesterol concentration was calculated by the Friedewald formula. Fibrinogen in plasma (mmol/l) was determined by spectrometric test. The participants stated in the questionnaire whether they previously had had a heart attack, angina pectoris, chest pain at physical exertion or mental strain, heart failure, stroke, vascular spasms in calves ("window watcher syndrome") or diabetes.

\section{Assessment of managerial leadership at work}

The participants rated their managers' behaviours using an assessment instrument which included 10 items with structured response scales (see table 4). These items constitute one dimension, leadership climate, of the psychosocial work environment measured in the Stress Profile. The Stress Profile is a validated instrument based upon consultation at work sites and established theories and research on work stress. ${ }^{28}$ The internal consistency for this scale was high (Cronbach $\alpha$ of 0.86 ) suggesting that a supervisor tends to either express all these behaviours or none of them. We summed the response scores and expressed this as a percentage of the theoretical maximum (100 refers to respondents with the highest score for every item of the scale; 0 refers to respondents with the lowest score for every item of the scale).

\section{Follow-up}

Hard endpoint outcomes for IHD were defined as hospital admission with a main diagnosis registered as acute myocardial infarction (the International Classification of Diseases, version 9
(ICD-9) code 410; ICD-10 code I21) or unstable angina (ICD-9: 411; ICD-10: I20.0); or death with a registered underlying cause of IHD (ICD-9: 410-414; ICD-10: I20-I25) or cardiac arrest (ICD-9: 427; ICD-10: I46). Records of hospital admissions and deaths from 14 March 1963 until 31 December 2003 were obtained. Incident caseness was defined as the first event occurring after baseline screening, excluding prevalent cases at baseline.

\section{Statistical analysis}

For each IHD outcome, the time to the event was defined as the number of days between baseline screening and the first diagnosis after baseline but before 31 December 2003. For employees with no events, the end of follow-up was 31 December 2003 or the date of death if earlier. Outcome of the primary analysis was a composite measure of acute myocardial infarction, unstable angina and cardiac death. Subsidiary analysis excluded unstable angina from the outcome to examine whether the association was seen with myocardial infarction and cardiac death only. We calculated age-adjusted hazard ratios with $95 \%$ confidence intervals from Cox proportional-hazards analyses for incident IHD per 1 standard deviation (SD) increase in standardised leadership score (mean 0, SD 1). Additional adjustments included socioeconomic characteristics and conventional risk factors. An interaction term between leadership and time worked in the current workplace was entered in a subsidiary analysis. SAS v 9.1 was used for the analyses.

\section{RESULTS}

Descriptive statistics for the sample are shown in table 1 . The participants were on average 42 years old and most of them were relatively highly educated and non-smokers. The comparatively favourable risk factor levels were due to the fact that all participants were employed, and that the sample was composed of employees with higher education than the average employee in Sweden and slightly better health care support than the average inhabitant in Stockholm.

A total of 74 incident IHD events occurred during the mean follow-up time of 9.7 years (range: 3 days to 10.5 years). In ageadjusted analysis, a higher leadership score was associated with a lower IHD risk. This inverse association was dependent on the time worked in the current workplace $(p=0.049$ for the interaction between leadership score and time worked in current workplace on incident IHD including unstable angina and $p=0.03$ on acute myocardial infarction and cardiac death excluding unstable angina). As illustrated in table 2, the association was stronger the longer the participant had worked in the same workplace. This suggests a dose-response association between leadership and incident IHD.

Table 3 presents the effects of multiple adjustments on the inverse association between leadership score and incident IHD among participants with complete data on all baseline characteristics and a minimum of 4 years in the current workplace. The association was robust to adjustments for socioeconomic factors and conventional risk factors for ischaemic disease. To assess possible reverse causality, we excluded those with self-reported angina, chest pain, vascular spasms in their calves, heart attack, heart failure or stroke at baseline $(n=172)$. In age-adjusted models of men with a minimum of 4 years in the current workplace, the hazard ratio for incident IHD was 0.63 (95\% CI 0.46 to $0.86, p=0.005)$.

Finally, we examined the association of each leadership scale item with incident IHD (table 4). Except for three items (item 4: 
"I have a clear picture of what my boss expects of me", item 8: "My boss encourages my participation in the scheduling of my work", and item 10: "I am criticised by my boss if have done something that is not good"), all of the items in the leadership scale were significantly associated with incident IHD.

\section{DISCUSSION}

This study of a contemporary cohort of working men in Sweden suggests an association between managerial leadership and incident IHD among employees, independent of a number of conventional risk factors. The managerial practices measured cover aspects of the manager's consideration for the individual employee, provision of clarity in goals and role expectations, supplying information and feedback, ability to carry out changes at work successfully, and promotion of employee participation and control.

Our results are in agreement with previous studies on organisational justice and social support, that is, the extent to which people perceive that they are treated fairly and supported by their supervisors. Two independent occupational cohort studies showed a lower risk of incident CHD and cardiovascular mortality among employees who experienced a high level of

Table 1 Sample characteristics: the WOLF Stockholm study

\begin{tabular}{|c|c|c|}
\hline Risk factor at baseline & Men, $\mathbf{n}$ & Mean (SD) or \% \\
\hline Age, years & 3122 & $41.6(11.1)$ \\
\hline \multicolumn{3}{|l|}{ Educational attainment } \\
\hline High & 1677 & 53.8 \\
\hline Intermediate & 892 & 28.6 \\
\hline Low & 547 & 17.6 \\
\hline \multicolumn{3}{|l|}{ Social class } \\
\hline Professional and higher manager & 632 & 23.3 \\
\hline Technical, lower management & 727 & 26.8 \\
\hline Non-manual & 239 & 8.8 \\
\hline Skilled manual & 496 & 18.3 \\
\hline Unskilled manual & 623 & 22.9 \\
\hline \multicolumn{3}{|l|}{ Supervisory status } \\
\hline Yes & 702 & 22.7 \\
\hline No & 2386 & 77.3 \\
\hline Mean income per year, 1000 & 3104 & $253.11(137.98)$ \\
\hline \multicolumn{3}{|l|}{ Swedish kronor } \\
\hline \multicolumn{3}{|l|}{$\begin{array}{l}\text { Perceived physical load at work (proxy } \\
\text { quartiles) }\end{array}$} \\
\hline $0-1$ & 790 & 25.1 \\
\hline $2-4$ & 822 & 26.1 \\
\hline $5-6$ & 558 & 17.7 \\
\hline $7-14$ & 976 & 31.0 \\
\hline \multicolumn{3}{|l|}{ Physical exercise } \\
\hline Never or very little & 785 & 24.9 \\
\hline Now and then & 1153 & 36.5 \\
\hline Regularly & 1221 & 38.7 \\
\hline \multicolumn{3}{|l|}{ Smoking status } \\
\hline Never smoker & 1417 & 46.4 \\
\hline Ex-smoker & 894 & 29.3 \\
\hline Current & 742 & 24.3 \\
\hline Body mass index, $\mathrm{kg} / \mathrm{m}^{2}$ & 3119 & $25.2(3.3)$ \\
\hline Systolic blood pressure, $\mathrm{mm} \mathrm{Hg}$ & 3118 & $123(14)$ \\
\hline Diastolic blood pressure, $\mathrm{mm} \mathrm{Hg}$ & 3118 & $75(10)$ \\
\hline Total cholesterol, $\mathrm{mmol} / \mathrm{l}$ & 3122 & $5.48(1.15)$ \\
\hline Total:HDL cholesterol ratio & 3121 & $4.29(1.45)$ \\
\hline Triglycerides, mmol/l & 3122 & $1.40(1.02)$ \\
\hline Fibrinogen, mmol/l & 3121 & $2.69(0.73)$ \\
\hline Diabetes & 3100 & 1.4 \\
\hline
\end{tabular}

HDL, high density lipoprotein. organisational justice. ${ }^{20} 29$ A small-scale study found that the ambulatory systolic blood pressure of employees with multiple supervisors was $15 \mathrm{mmHg}$ lower on days worked under a supervisor perceived as fair than on days worked under an unfavourably perceived supervisor. ${ }^{30}$ A strength of the present study is the focus on very concrete managerial behaviours which may be useful when implementing workplace interventions.

In the leadership behaviours scale, the strongest predictors of IHD (with hazard ratios below 0.66) were items stating that the manager gives information and sufficient control to employees in relation to their responsibilities, explains goals and subgoals thoroughly, and is good at pushing through and carrying out changes. Employee preferences regarding managerial behaviours have been shown to differ between cultures, and the behaviours described above (ie, change-oriented and allowing a high degree of employee control) are in accordance with what is considered good managerial practice in Sweden. ${ }^{31-33}$ Highly educated employees were over-represented in this sample and more independence can be assumed to be preferred and successfully handled by such qualified personnel. It should not be forgotten that our findings were based on men only; the relationship may look different for women.

At least two items of the 10 -item leadership behaviours scale are similar to the general conceptualisations of the DemandControl Model (item 6) and social support (item 5). In our previous study of this same cohort, job strain (ie, high job demands combined with low job control) was associated with IHD, but not as strongly as managerial leadership was in the present study. ${ }^{34}$ The leadership scale shows a moderate correlation with the Demand-Control Questionnaire social support scale (Spearman's correlation coefficient 0.44), suggesting that the leadership scale overlaps with the social support scale, but still has independent quality. ${ }^{35}$

Three items of the leadership behaviours scale (items 1, 5 and 9) were close to operationalisations of organisational justice and effort reward imbalance (validated measures of those concepts were unfortunately not available from the WOLF study). Regarding leadership theories, the leadership behaviours scale more strongly resembles task oriented and transactional leadership behaviours than relationship oriented and transformational leadership behaviours, although the latter is often seen as a stronger correlate of employees' self-reported health.

Plausible mechanisms for the association between managerial leadership and CHD remain unclear. Recent publications on the relationship between managerial leadership and subordinate self-reported health have stressed the importance of negative aspects of managerial behaviours (eg, passive-avoidant and laissez-faire leadership). ${ }^{22}{ }^{23}$ Skogstad et al found laissez-faire leadership behaviours to be positively associated with employee role conflicts, role ambiguity and conflicts with co-workers. Psychosocial stress has been shown to increase the progression of coronary atherosclerosis. ${ }^{36}$ One could speculate that a present and active manager, providing structure, information and support, counteracts destructive processes in work groups, thereby promoting regenerative rather than stress-related physiological processes in employees.

We measured managerial behaviours using staff surveys; thus, the responses could reflect individual differences in perceiving leadership as well as actual behaviours exhibited by managers. A previous study has shown that work group perceptions of leadership differ from individual perceptions, and it was claimed that the latter better explain individuals' health and sick leave. ${ }^{37}$ However, another study showed significant variance between 
Table 2 Dose-response association between managerial leadership and incident ischaemic heart disease among employees

\begin{tabular}{|c|c|c|c|c|c|}
\hline $\begin{array}{l}\text { Years at current workplace } \\
\text { prior to survey (years)* }\end{array}$ & Men, $\mathbf{n}$ & \multicolumn{2}{|c|}{$\begin{array}{l}\text { Risk for incident IHD (including unstable angina) } \dagger \\
\text { per } 1 \text { SD increase in leadership score }\end{array}$} & \multicolumn{2}{|c|}{$\begin{array}{l}\text { Risk for incident IHD (excluding unstable angina) } \\
\text { per } 1 \text { SD increase in leadership score }\end{array}$} \\
\hline Any amount of years & 3122 & 74 & $0.80(0.64$ to 0.99$)$ & 54 & $0.79(0.62$ to 1.02$)$ \\
\hline At least 1 year & 2423 & 63 & $0.76(0.61$ to 0.96$)$ & 44 & $0.72(0.55$ to 0.94$)$ \\
\hline At least 2 years & 2012 & 58 & 0.77 (0.61 to 0.97$)$ & 40 & 0.73 (0.55 to 0.97$)$ \\
\hline At least 3 years & 1768 & 51 & $0.69(0.54$ to 0.88$)$ & 34 & $0.66(0.49$ to 0.88$)$ \\
\hline At least 4 years & 1468 & 44 & $0.61(0.47$ to 0.80$)$ & 29 & 0.55 (0.40 to 0.77$)$ \\
\hline
\end{tabular}

Age-adjusted hazard ratio is per 1 SD increase in standardised leadership index score (mean 0, SD 1).

*Based on Statistic Sweden records (the number of years the participant had worked in the workplace prior to filling out the leadership questionnaire).

† Includes acute myocardial infarction (ICD-10: I21) or unstable angina (ICD-10: I20.0) necessitating hospitalisation or death from ischaemic heart disease (ICD-10:I20-I25) or cardiac arrest (ICD-10: 146).

fIncludes acute myocardial infarction (ICD-10: I21) necessitating hospitalisation or death from ischaemic heart disease (ICD-10: I20-I25) or cardiac arrest (ICD-10: I46).

IHD, ischaemic heart disease.

work groups in perceptions of managerial leadership, and a strong average within-group agreement, indicating a homogeneity in perceptions among employees working under the same supervisor, not explained by individual characteristics. ${ }^{38}$ Individual perceptions could also to some extent reflect the fact that managers actually behave differently towards different employees since the relationship is a reciprocal process. ${ }^{39}$

The number of years the respondents had been working for the same employer at the time of the survey was obtained from Statistics Sweden. This information provides an objective approximation of pre-survey exposure to the rated leadership qualities. The dose-response relationship between increased exposure time and decreased disease risk supports the possibility that the association between managerial behaviours and IHD reflects actual workplace influences rather than solely being determined by individual differences in perception. However, time worked for the same employer does not necessarily mean time worked for the same manager or supervisor. Changes in managers and supervisors may have occurred but are likely to dilute rather than inflate the observed effects.

Subjectivity bias in ascertainment of disease status is an increasingly recognised validity problem in studies on psychosocial factors and IHD. In a previous study of Scottish men, for example, the association between self-reported stress and CHD was largely driven by diagnoses based on symptom reporting. ${ }^{40}$ In the present study, the outcomes included only cardiovascular deaths and hospital admissions for diagnoses based on objective criteria (eg, ECG, enzymes, and CT or MRI imaging) of ischaemic disease. Conditions influenced by subjective reporting (eg, hospital admission from ill defined heart disease, haemorrhoids

Table 3 Association of standardised leadership score with incident IHD among employees after adjustment for different risk factors at baseline*

\begin{tabular}{ll}
\hline & $\begin{array}{l}\text { Hazard ratio for IHD } \\
\text { per } 1 \text { SD increase } \\
\text { in leadership score } \\
\text { (95\% CI) }\end{array}$ \\
Adjustment variables in addition to age & 0.65 (0.49 to 0.87) \\
\hline None & 0.67 (0.49 to 0.90) \\
$\begin{array}{l}\text { Education, supervisory status, social class, income } \\
\text { and physical load at work }\end{array}$ & 0.65 (0.49 to 0.87) \\
$\begin{array}{l}\text { Smoking, physical exercise } \\
\text { BMI, systolic and diastolic blood pressure, total } \\
\text { cholesterol, total/HDL cholesterol ratio, triglycerides, } \\
\text { fibrinogen, diabetes }\end{array}$ & 0.61 (0.46 to 0.82) \\
$\begin{array}{l}\text { All of the above } \\
\text { * Only those with a minimum of 4-year exposure and no missing data in any of the }\end{array}$ \\
$\begin{array}{l}\text { predictors were included in these models ( } \mathrm{n}=1319,40 \text { events). } \\
\text { Ischaemic heart disease (IHD) included unstable angina. HDL, high density lipoprotein. }\end{array}$
\end{tabular}

or "other" circulatory disorders) or self-reported data (eg, Rose angina) were excluded. Thus, bias due to misclassification of disease is an unlikely explanation of our findings.

In a study of Finnish middle-aged men, occupational, but not leisure time, physical activity was a strong predictor of 11-year progression of carotid atherosclerosis, especially in those with pre-existing IHD. Job strain had no significant effect after occupational physical activity was accounted for. ${ }^{41}$ Virkkunen et al found physical workload to be an important predictor of increased systolic blood pressure, which is a key pathway to CHD risk. ${ }^{42}$ Socioeconomic position is another potential confounder. ${ }^{43}$ In the present study, analyses were controlled for perceived physical load at work, physical exercise, and multiple indicators of socioeconomic position, including education, social class, income and supervisory status. We did not find evidence of major confounding, as the association between

Table 4 Association of standardised leadership scale items with incident IHD among employees with a minimum 4-year exposure

\begin{tabular}{|c|c|c|}
\hline Items & $\begin{array}{l}\text { Participants, } \\
\text { n (events, n) }\end{array}$ & $\begin{array}{l}\text { Age-adjusted } \\
\text { hazard ratio } \\
\text { for IHD per } \\
1 \text { SD increase } \\
\text { in leadership } \\
\text { score }(95 \% \mathrm{CI})\end{array}$ \\
\hline $\begin{array}{l}\text { 1. My boss gives me the information I } \\
\text { need }\end{array}$ & $1463(44)$ & $0.65(0.50$ to 0.83$)$ \\
\hline $\begin{array}{l}\text { 2. My boss is good at pushing through } \\
\text { and carrying out changes }\end{array}$ & $1441(44)$ & $0.61(0.45$ to 0.81$)$ \\
\hline $\begin{array}{l}\text { 3. My boss explains goals and subgoals } \\
\text { for our work so that I understand what } \\
\text { they mean for my particular part of the } \\
\text { task }\end{array}$ & $1453(44)$ & $0.61(0.46$ to 0.79$)$ \\
\hline $\begin{array}{l}\text { 4. I have a clear picture of what my boss } \\
\text { expects of me }\end{array}$ & $1454(44)$ & $0.77(0.59$ to 1.01$)$ \\
\hline $\begin{array}{l}\text { 5. My boss shows that he/she cares how } \\
\text { things are for me and how I feel }\end{array}$ & $1455(44)$ & $0.71(0.54$ to 0.93$)$ \\
\hline $\begin{array}{l}\text { 6. I have sufficient power in relation to my } \\
\text { responsibilities }\end{array}$ & 1442 (44) & $0.64(0.48$ to 0.84$)$ \\
\hline $\begin{array}{l}\text { 7. My boss takes the time to become } \\
\text { involved in his/her employees' } \\
\text { professional development }\end{array}$ & $1447(44)$ & $0.69(0.51$ to 0.92$)$ \\
\hline $\begin{array}{l}\text { 8. My boss encourages my participation } \\
\text { in the scheduling of my work }\end{array}$ & $1446(44)$ & $0.84(0.63$ to 1.12$)$ \\
\hline $\begin{array}{l}\text { 9. I am praised by my boss if I have done } \\
\text { something good }\end{array}$ & $1452(44)$ & 0.55 to 0.97$)$ \\
\hline $\begin{array}{l}\text { 10. I am criticised by my boss if I have } \\
\text { done something that is not good }\end{array}$ & $1452(44)$ & $1.03(0.77$ to 1.38$)$ \\
\hline
\end{tabular}




\section{Main messages}

There is a prospective, dose-response relationship between concrete managerial behaviours and ischaemic heart disease among employees.

\section{Policy implications}

If the association between concrete managerial behaviours and ischaemic heart disease among employees is causal, then workplace health promotion interventions could focus on the managers' concrete behaviours, such as the provision to employees of clear work objectives, information and sufficient power in relation to their responsibilities.

managerial leadership and employee IHD was little affected by these adjustments.

In conclusion, this is apparently the first study to provide evidence of a prospective, dose-response relationship between concrete managerial behaviours and objectively assessed IHD among employees. If the association is causal, this study suggests that interventions aimed at improving the psychosocial work environment and preventing ischaemic heart disease among employees could focus on concrete managerial behaviours, such as the provision of clear work objectives, information and sufficient control in relation to responsibilities.

Acknowledgements: We would like to thank Dr Gabriel Oxenstierna for the original idea of merging the databases, making this study possible.

Funding: AN, TT and HW are financed by a research program grant from the Swedish Council for Working Life and Social Research (FAS, grant no. 2004-2021). MK is supported by the Academy of Finland (projects 117614, 124322 and 124271) and the Finnish Environment Fund. The WOLF study was originally established by the Swedish Council for Working Life and Social Research (FAS grant no. 2001-0163). The study sponsors have not been involved in the research process.

Competing interests: None.

Ethics approval: The Regional Research Ethics Board in Stockholm, and the ethics committee at Karolinska Institutet, Stockholm, Sweden approved the study (nos. 2006/158-31, 2008/240-32, 92-198 and 03-125).

\section{REFERENCES}

1. Kivimäki M, Virtanen $M$, Elovainio $M$, et al. Work stress in the etiology of coronary heart disease: a meta-analysis. Scand J Work Environ Health 2006;32:431-42.

2. Allvin M, Aronsson G. The future of work environment reforms: does the concept of work environment apply within the new economy? In: Thörnqvist A, ed. Work life, work environment and work safety in transition: historical and sociological perspectives on their development in Sweden during the 20th century. Stockholm: National Institute for Working Life, 2001:237-49.

3. Nyberg A, Bernin P, Theorell T. The impact of leadership on the health of subordinates. Report no 1. Stockholm: SALTSA, 2005.

4. Sheridan JE, Vredenburgh DJ. Structural model of leadership influence in a hospital organization. Acad Manage J 1979;22:6-21.

5. Melchior MEW, van den Berg AA, Halfens R, et al. Burnout and the work environment of nurses in psychiatric long-stay care settings. Soc Psychiatry Psychiatr Epidemiol 1997;32:158-64.

6. Mccain AK. The relationship between head nurse leadership behaviour and staff nurse burnout. Dissertation Abstracts International Section B 1995:56(5-B). Ann Arbor: University Microfilms International.

7. Harris CA. The relationship between principal leadership styles and teacher stress in low socioeconomic urban elementary schools as perceived by teachers. Dissertation Abstracts International 1999;60(6-A). Ann Arbor: University Microfilms International.

8. Wilcoxon SA. Leadership behavior and therapist burnout: a study of rural agency settings. J Rural Community Psychol 1989;10:3-14.

9. Seltzer J, Numerof RE. Supervisory leadership and subordinate burnout. Acad Manage J 1988:31:439-46.

10. Duxbury ML, Armstrong GD, Drew DJ, et al. Head nurse leadership style with staff nurse burnout and job satisfaction in neonatal intensive care units. Nurs Res 1984:33:97-101.
11. Bass BM. Does the transactional-transformational leadership paradigm transcend organizational and national boundaries? Am Psychol 1997;52:130-9.

12. Corrigan PW, Diwan S, Campion J, et al. Transformational leadership and the mental health team. Adm Policy Ment Health 2002;30:97-108.

13. Sosik JJ, Godshalk VM. Leadership styles, mentoring functions received and jobrelated stress: a conceptual model and preliminary results. J Organ Behav 2000;21:365-90.

14. Moorman RH. Relationship between organizational justice and organizational citizenship behaviors: do fairness perceptions influence employee citizenship? J App/ Psychol 1991;76:845-55.

15. Elovainio M, Kivimäki M, Helkama K. Organizational justice evaluations, job control, and occupational strain. J Appl Psychol 2001;86:418-24.

16. Elovainio M, Kivimäki M, Vahtera J. Organizational justice: evidence of a new psychosocial predictor of health. Am J Public Health 2002;92:105-8.

17. Kivimäki M, Elovainio M, Vahtera J, et al. Organisational justice and health of employees: prospective cohort study. Occup Environ Med 2003;60:27-34.

18. Folger R, Cropanzano R. Organizational justice and human resource management. Thousand Oaks, CA: Sage, 1998.

19. Ferrie JE, Head J, Shipley MJ, et al. Injustice at work and incidence of psychiatric morbidity: the Whitehall II Study. Occup Environ Med 2006;63:443-50.

20. Kivimaki M, Ferrie JE, Brunner E, et al. Justice at work and reduced risk of coronary heart disease among employees: the Whitehall II Study. Arch Intern Med 2005; 165:2245-51.

21. Tepper BJ. Consequences of abusive supervision. Acad Manage J 2000;43:178-90.

22. Arnold KA, Turner N, Barling J, et al. Transformational leadership and psychological well-being: the mediating role of meaningful work. J Occup Health Psychol 2007; 12:193-203

23. Skogstad A, Einarsen S, Torsheim T, et al. The destructiveness of laissez-faire leadership behaviour. J Occup Health Psychol 2007;12:80-92.

24. Johnson JV, Hall EM. Job strain, work place social support, and cardiovascular disease: a cross-sectional study of a random sample of the Swedish working population. Am J Public Health 1988;78:1336-42.

25. Johnson JV, Hall EM, Theorell T. Combined effects of job strain and social isolation on cardiovascular disease morbidity and mortality in a random sample of the Swedish male working population. Scand J Work Environ Health 1989;15:271-9.

26. Vahtera J, Kivimäki M, Pentti J, et al. Effect of change in the psychosocial work environment on sickness absence: a 7-year follow-up of initially healthy employees J Epidemiol Community Health 2000:54:484-93.

27. Theorell T, Emdad R, Arnetz B, et al. Employee effects of an educational program for managers at an insurance company. Psychosom Med 2001;63:724-33.

28. Setterlind S, Larsson G. The Stress Profile: a psychosocial approach to measuring stress. Stress Med 1995;11:85-92.

29. Elovainio M, Leino-Arjas P, Vahtera J, et al. Justice at work and cardiovascular mortality: a prospective cohort study. J Psychosom Res 2006;61:271-4.

30. Wager N, Fieldman G, Hussey T. The effect on ambulatory blood pressure of working under favourably and unfavourably perceived supervisors. Occup Environ Med 2003;60:468-74.

31. House RJ, Wright NS, Aditya RN. Cross-cultural research on organizational leadership. A critical analysis and a proposed theory. In: Earley PC, Erez M, eds. New perspectives in international industrial/organizational psychology. San Francisco: The New Lexington Press, 1997.

32. Brodbeck F, Frese M, Akerblom S, et al. Cultural variation of leadership prototypes across 22 European countries. J Occup Organ Psychol 2000;73:1-29.

33. Holmberg I, Ảkerblom S. Modelling leadership - implicit leadership theories in Sweden. Scand J Management 2006;22:307-29.

34. Kivimaki M, Theorell $\mathrm{T}$, Westerlund $\mathrm{H}$, et al. Job strain and ischemic disease - does the inclusion of older employees in the cohort dilute the association? The WOLF Stockholm study. J Epidemiol Community Health 2008:62:372-4.

35. Karasek R, Theorell T. Healthy work: stress, productivity, and the reconstruction of working life. New York: Basic Books, 1990:68-76.

36. Wang HX, Leineweber C, Kirkeeide R, et al. Psychosocial stress and atherosclerosis: family and work stress accelerate progression of coronary disease in women. The Stockholm Female Coronary Angiography Study. J Intern Med 2007:261:245-54.

37. Svensen E. Work \& Health - cognitive activation theory of stress applied in an organisational setting. Dissertation for PhD. Bergen: University of Bergen, 2007.

38. Kouvonen A, Kivimäki $\mathrm{M}$, Elovainio $\mathrm{M}$, et al. Low organisational justice and heavy drinking: a prospective cohort study. Occup Environ Med 2008;65:44-50.

39. van Dierendonck D, Haynes $C$, Borrill $C$, et al. Leadership behavior and subordinate well-being. J Occup Health Psychol 2004:9:165-75.

40. Macleod J, Davey Smith G, Heslop P, et al. Psychological stress and cardiovascular disease: empirical demonstration of bias in a prospective observational study of Scottish men. BMJ 2002;324:1-7.

41. Krause N, Brand RJ, Kaplan GA, et al. Occupational physical activity, energy expenditure and 11-year progression of carotid atherosclerosis. Scand J Work Environ Health 2007;33:405-24

42. Virkkunen H, Härmä M, Kauppinen T, et al. Shift work, occupational noise and physical workload with ensuing development of blood pressure and their joint effect on the risk of coronary heart disease. Scand J Work Environ Health 2007:33:401-4.

43. Macleod J, Davey Smith G, Heslop P, et al. Limitations of adjustment for reporting tendency in observational studies of stress and self reported coronary heart disease. J Epidemiol Community Health 2002:56:76-7. 
Care-home worker's personal exposure

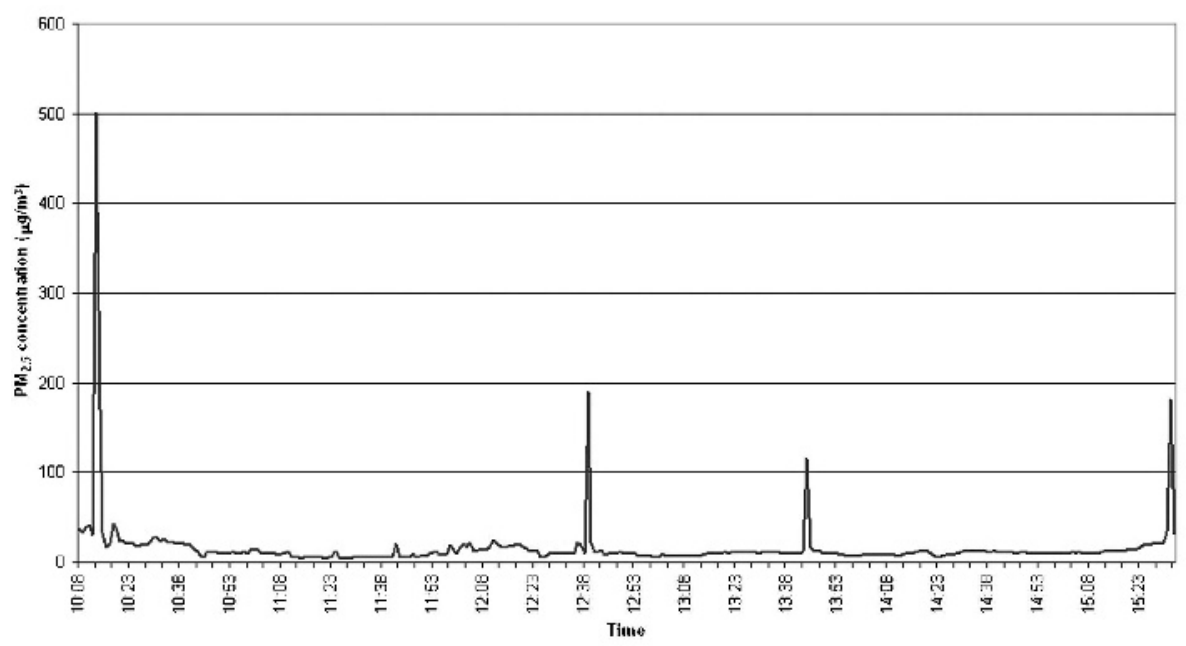

Figure 1 Care-home worker's personal exposure.

time-concentration plot for a typical nonsmoking care-home worker over a work shift. Overall, the workers' personal $\mathrm{PM}_{2.5}$ exposure levels were much lower than those recorded in the smoking rooms with the geometric mean of the eight work-shift measurements being $24 \mu \mathrm{g} / \mathrm{m}^{3}$ (range 9-110 $\mu \mathrm{g} / \mathrm{m}^{3}$ ). On average, care-home worker exposures to SHS were nearly 10 times lower than those recorded in the hospitality sector in Scotland (before the introduction of smoke-free legislation) where full shift $\mathrm{PM}_{2.5}$ levels were recorded between 27 and 1070 with a geometric mean value of $202 \mu \mathrm{g} / \mathrm{m}^{3}$.

Salivary cotinine data from non-smoking workers $(n=36)$ within these eight carehomes confirmed that exposure to SHS at work is low. The geometric mean salivary cotinine level in these care-home workers was $0.37 \mathrm{ng} / \mathrm{ml}$ prior to the introduction of the smoke-free legislation in March 2006 compared with $2.94 \mathrm{ng} / \mathrm{ml}$ in bar workers. ${ }^{2}$ Non-smoking care-home workers' levels reduced to $0.17 \mathrm{ng} / \mathrm{ml}$ in the months after implementation of the legislation. It seems likely that this fall in cotinine levels arose from reduced exposure in social settings outside of work and is reflected in data from a population survey showing levels in non-smoking adults reducing by $39 \%$ from $0.43 \mathrm{ng} / \mathrm{ml}$ to $0.26 \mathrm{ng} / \mathrm{ml}$ after introduction of the restrictions on smoking in enclosed public places in Scotland. ${ }^{4}$

This is a small study and further work is needed to confirm that exposures of staff in care-homes and other situations where there are exemptions are adequately controlled.

\section{S Semple, ${ }^{1,2}$ A Naji, ${ }^{1}$ S Haw, ${ }^{3,4}$ J G Ayres ${ }^{5}$}

${ }^{1}$ Scottish Centre for Indoor Air, School of Medicine, University of Aberdeen, UK; ${ }^{2}$ Institute of Occupational Medicine, Edinburgh, UK; ${ }^{3} \mathrm{NHS}$ Health Scotland, Edinburgh, UK; ${ }^{4}$ Scottish Collaboration for Public Health Research \& Policy (SCPHRP), MRC Human Genetics Unit, Edinburgh, UK: ${ }^{5}$ Institute of Occupational \& Environmental Medicine, University of Birmingham, Birmingham, UK

Correspondence to: Sean Semple, Scottish Centre for Indoor Air, Liberty Safe Work Centre, Foresterhill Road Aberdeen AB25 2ZP, UK; sean.semple@abdn.ac.uk
Competing interests: None declared.

Provenance and peer review: Not commissioned; not externally peer reviewed.

Accepted 16 January 2009

Occup Environ Med 2009;66:639-640.

doi:10.1136/oem.2009.045864

\section{REFERENCES}

1. Semple S, Creely KS, Naji A, et al. Secondhand smoke levels in Scottish pubs: the effect of smoke-free legislation. Tob Control 2007;16:127-32.

2. Semple S, Maccalman L, Naji AA, et al. Bar workers exposure to second-hand smoke: the effect of Scottish smoke-free legislation on occupational exposure. Ann Occup Hyg 2007:51:571-80.

3. US Environmental Protection Agency. Air quality guidelines. http://airnow.gov/index.cfm?action= aqibroch.index (accessed 18 Dec 2008)

4. Haw SJ, Gruer L. Changes in exposure of adult nonsmokers to secondhand smoke after implementation of smoke-free legislation in Scotland: national cross sectional survey. BMJ 2007;335:549

\section{CORRECTION}

doi:10.1136/oem.2008.039362corr1

A Nyberg, L Alfredsson, T Theorell, et al Managerial leadership and ischaemic heart disease among employees: the Swedish WOLF study (Occup Environ Med 2009;66:51-5). The age-adjusted hazard ratio is missing for item 9 in table 4 . The correct table is printed below.

Table 4 Association of standardised leadership scale items with incident IHD among employees with a minimum 4-year exposure

\begin{tabular}{lll}
\hline Items & $\begin{array}{l}\text { Participants, } \mathbf{n} \\
\text { (events, } \mathbf{n})\end{array}$ & $\begin{array}{l}\text { Age-adjusted hazard ratio for IHD } \\
\text { per 1 SD increase in leadership } \\
\text { score (95\% CI) }\end{array}$ \\
\hline 1. My boss gives me the information I need & $1463(44)$ & 0.65 (0.50 to 0.83) \\
2. My boss is good at pushing through and carrying out & $1441(44)$ & 0.61 (0.45 to 0.81$)$
\end{tabular}
changes

3. My boss explains goals and sub-goals for our work so that I 1453 (44) understand what they mean for my particular part of the work

4. I have a clear picture of what my boss expects of me 1454 (44)

5. My boss shows that he/she cares how things are for me and 1455 (44) how I feel

6. I have sufficient power in relation to my responsibilities 1442 (44)

$0.61(0.46$ to 0.79$)$

7. My boss takes the time to become involved in his/her 1447 (44)

$0.77(0.59$ to 1.01$)$

$0.71(0.54$ to 0.93$)$

0.64 ( 0.48 to 0.84$)$

employees' professional development

8. My boss encourages my participation in the scheduling of 1446 (44) 0.84 (0.63 to 1.12 ) my work

9. I am praised by my boss if I have done something good 1452 (44)

$0.73(0.55$ to 0.97$)$

10. I am criticised by my boss if I have done something that is 1452 (44)

$1.03(0.77$ to 1.38$)$ not good

Response format: 1: “No, never"; 2: “No, seldom"; 3: "Yes, sometimes”; 4: "Yes, often”. Internal consistency (Cronbach $\alpha)=0.86$.

IHD, ischaemic heart disease. 